\title{
DISSEMINATED NOCARDIOSIS WITH PSOAS ABSCESS IN A PATIENT WITH AIDS: FIRST REPORTED CASE
}

\author{
Marcelo CORTI(1), Rubén SOLARI(1), Luis DE CAROLIS(1), Diana CANGELOSI(1), Mario BIANCHI(2) \& Ricardo NEGRONI(2)
}

\begin{abstract}
SUMMARY
Psoas muscle abscess is an uncommon infection that have been diagnosed increasingly in the last years. We present a case of a patient with advanced human immunodeficiency virus infection who developed a disseminated infection due to Nocardia asteroides sensu stricto type VI with psoas abscess. To our knowledge no other cases of Nocardia psoas abscess in the setting of HIV infection have been reported in the literature.
\end{abstract}

KEYWORDS: Nocardia asteroides; Psoas abscess; HIV; AIDS.

\section{INTRODUCTION}

In immunocompetent patients, nocardiosis usually presents as cutaneous or subcutaneous lesions and is generally caused by Nocardia brasiliensis. On the other hand, disseminated disease is often seen in immunocompromised patients, including patients with human immunodeficiency virus (HIV) infection, and Nocardia asteroides complex is the most common etiology in these $\operatorname{cases}^{2,7}$.

The genus Nocardia has recently been revised and a number of new groups has been included within the genus ${ }^{3,7}$.

We report a case of an AIDS patient who developed a disseminated nocardiosis due to Nocardia asteroides sensu stricto type VI with multiple soft tissue and muscle abscesses, including a psoas abscess.

\section{CASE REPORT}

A 32-year-old man, infected with the HIV and hepatitis C virus, was admitted in our division of HIV/AIDS disease with three weeks history of fever, abdominal pain, cough and weight loss. He had diagnosis of AIDS since 1997 when he developed an episode of esophagitis due to Candida albicans and later, multiple episodes of bacterial pneumonia. His past medical history was significant for smoking, alcoholism and intravenous drug abuse. He never received antiretroviral therapy.

The physical examination revealed a bad general state, fever $\left(39^{\circ} \mathrm{C}\right)$ and multiple soft tissue abscesses with pain, tender and inflammatory swelling located at the left forearm and the left thigh. Pulmonary auscultation was significant for rales in the left basal lobe. A chest Xray showed a left perihilar infiltrate (Fig. 1). Relevant laboratory findings were: hemoglobin $6.4 \mathrm{~g} / \mathrm{dL}$; hematocrit $19.2 \%$; white blood

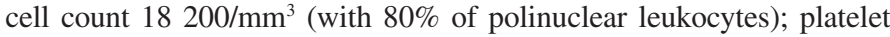
count $120000 / \mathrm{mm}^{3}$ and the erythrocyte sedimentation rate was 138 $\mathrm{mm} / \mathrm{h}$. Transaminases levels, kidney function and coagulation tests were normal. The CD4 + T-cell count was of 32 cell $/ \mu \mathrm{L}$ and the plasma viral load was of 195831 copies/mL (5.30 $\log 10$ copies $/ \mathrm{mL})$. Blood and sputum cultures were negative for fungi, mycobacteria and common bacteria. Direct examination of sputum with Kinyoun stain showed

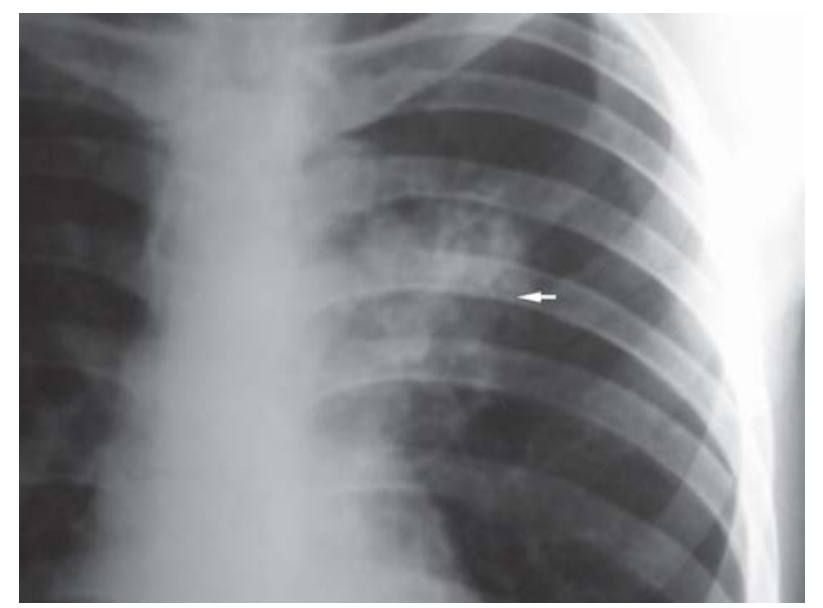

Fig. 1 - Chest X-ray showing the left parahilar infiltrate. 
acid-fast filamentous compatible with Nocardia spp. Abdominal ultrasonography revealed hepatomegaly with increased echogenicity, homogeneous splenomegaly and a hypoechoic soft tissue liquid collection consistent with abscess and located at the left paravertebral and psoas muscles (Fig. 2).

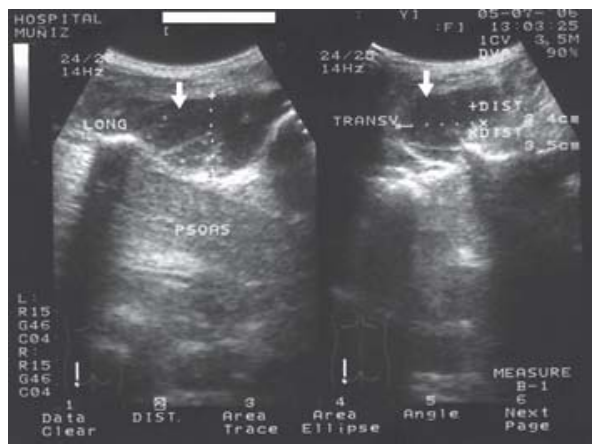

Fig. 2 - Abdominal ultrasound: hypoechoic soft tissue liquid collection of 180 x 61 x $62 \mathrm{~mm}$ in diameters consistent with abscess and located at the left paravertebral muscles.

A magnetic resonance imaging (MRI) was performed and revealed a heterogeneous collection hypointense in $\mathrm{T} 1$ and hypertense in $\mathrm{T} 2$, compatible with abscess, which enhanced with gadolinium and compromise the paravertebral left muscles, the maximus left gluteus and the left psoas. This image presented as multiloculated and also involved the iliac bone adjacent to the abscess (Fig. 3).

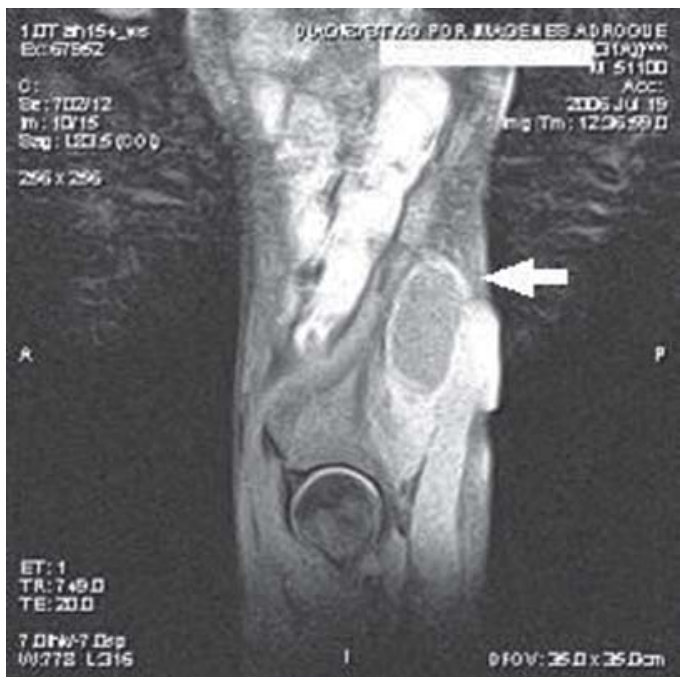

Fig. 3 - Magnetic resonance imaging showing the collection compatible with abscess involving the paravertebral muscles, maximus gluteus and the left psoas (arrow).

Aspiration of the suppurative left forearm and gluteus lesions showed abundant polinuclear leukocytes and acid-fast filamentous bacteria; the posterior culture grew a branched gram-positive and acidfast rod organism, which was further identified as Nocardia asteroides sensu stricto type VI.

Susceptibility of Nocardia asteroides to antimicrobial drugs was tested in vitro by the agar dilution method. Imipenem, amikacin and other aminoglycosides, trimethoprim-sulfathoxazole (cotrimoxazole), minocycline, ciprofloxacin and cefotaxime were shown to be the most active drugs with minimun inhibitory concentrations (MIC) levels nearly always lower than concentrations achievable in blood. Ampicillin and erythromicin were ineffectives.

The diagnosis of disseminated nocardiosis was made and the patient was treated with trimethoprim-sulfametoxazole (TMP-SMX) plus amikacin plus imipenem with a good clinical response. The patient was discharged one month after admission and continued with oral TMP-SMX plus ciprofloxacin.

\section{DISCUSSION}

The publications about Nocardia infections in patients with advanced HIV/AIDS disease has been recently increased. Disseminated nocardiosis is associated with multiple immunocompromising conditions such as HIV infection ${ }^{2,3}$.

Clinical and radiological manifestations of disseminated nocardiosis with pulmonary and muskuloeskeletal involvement are nonspecific and resemble the characteristics of disseminated Mycobacterium tuberculosis infection ${ }^{8}$. In the presence of fever with abdominal pain in a patient with HIV infection and severe immunosuppression a psoas abscess should be suspected. Increased leukocyte count and blood sedimentation rate are the most common, but unespecific, laboratory abnormalities, as we can see in our patient $t^{4,6}$.

Psoas abscess is a rare complication of disseminated infections in HIV-infected patients and can be secondary or primary ${ }^{6}$. NAVARRO LÓPEZ et $a l .{ }^{8}$ published a review of the medical literature about all cases of psoas abscess associated to HIV infection. The authors reported a total of 23 cases; in 13 patients, psoas abscess being considered as primary, with four lesions secondary to a bone focus, as in the patient now reported. In this series, Mycobacterium tuberculosis and Staphylococcus aureus were the two more frequent pathogens isolated as etiological agents of psoas abscesses. None of them were caused by Nocardia $\mathrm{spp}^{6}$.

Nocardia asteroides complex includes an heterogeneous group of microorganisms with similar biochemical, structure and antimicrobial resistance pattern. The members of this complex were subclassified into six different drug susceptibility types. This complex includes $N$. asteroides sensu stricto (isolated in our patient), N. farcinica, $N$. cyriacigeorgica, and $N$. nova ${ }^{1}$. This species corresponds to strains of drug pattern type VI. In the past few years, the importance of the identification of Nocardia species has been demonstrated, because the susceptibility to antimicrobial agents is not the same for the different species $^{5}$. The favourable evolution seen in our patient is in keeping with other cases described in the literature ${ }^{6}$.

The therapeutic management of psoas abscess is the same for patients with and without HIV infection. Ultrasound or computed tomography-guided drainage followed by antibiotic therapy are the first line strategies ${ }^{4,6}$.

Nocardial infections in patients with advanced HIV/AIDS disease are life-threatening diseases associated with high morbidity and mortality. Early diagnosis followed by and efficient, specific and long- 
CORTI, M.; SOLARI, R.; DE CAROLIS, L.; CANGELOSI, D.; BIANCHI, M. \& NEGRONI, R. - Disseminated nocardiosis with psoas abscess in a patient with AIDS: first reported case. Rev. Inst. Med. trop. S. Paulo, 50(2): 131-133, 2008.

lasting therapy based on susceptibility tests of Nocardia species are necessary to improve the prognosis of these patients. Differential diagnosis of soft tissue and muskuloskeletal involvement should be considered in patients with disseminated mycoses or tuberculosis because clinical (indolent course) and radiological findings (abscess formation) are similar, ${ }^{9}$.

The Medline, Embase, Lilacs and Cochrane databases were searched to identify articles of psoas abscess due to Nocardia spp. associated with AIDS. The search was performed using the following key words: psoas abscess, Nocardia, HIV and AIDS. To the best of our knowledge, psoas abscess due to Nocardia asteroides sensu stricto type VI has not been previously reported in the medical literature.

\section{RESUMO}

\section{Nocardiose disseminada com abscesso do psoas em paciente com} AIDS: primeiro caso relatado

O abscesso do músculo psoas é uma infecção pouco comum que tem sido diagnosticada de maneira crescente nos últimos anos. Apresentamos um caso de paciente com infecção avançada pelo vírus da imunodeficiência humana (HIV) que desenvolveu uma infecção disseminada por Nocardia asteroides senso estrito tipo VI, com abscesso no psoas.

Em nosso conhecimento, não foram relatados na literatura outros casos de abscesso do psoas por Nocardia, no contexto da infecção por HIV.

\section{REFERENCES}

1. BEAMAN, B.L. \& BEAMAN, L. - Nocardia species: host-parasite relationships. Clin. microbiol. Rev., 7: 213-264, 1994.

2. CECCHINI, D.; AMBROSIONI, J.C.; GOMEZ, A. et al. - Disseminated nocardiosis caused by Nocardia abscessus in an HIV-infected patient: first reported case. AIDS, 19: 1330-1331, 2005.

3. CORTI, M.E. \& VILLAFAÑE FIOTI, M.F. - Nocardiosis: a review. Int. J. infect. Dis., 7: 243-250, 2003.

4. CORTI, M.E.; PALMIERI, O.J.; VILLAFAÑE, M.F. \& MUZZIO, E. -Tuberculosis diseminada con absceso bilateral del psoas en un paciente con sida. Enferm. infec. Microbiol. clin., 22: 197-200, 2004.

5. DAHAN, K.; EL KABBAJ, D.; VENDITTO, M.; PASTURAL, M. \& DELA LOUSSE, M. - Intracranial nocardial recurrence during fluorinated quinolones therapy. Transpl. infect. Dis., 8: 161-165, 2006.

6. LERNER, P.I. - Nocardiosis. Clin. infect. Dis., 22: 891-903, 1996.

7. MOORE, S.L.; JONES, S. \& LEE, J.L. - Nocardia osteomyelitis in the setting of previously unknown HIV infection. Skeletal Radiol., 34: 58-60, 2005.

8. NAVARRO LÓPEZ, V.; LÓPEZ GARCÍA, F.; GONZÁLEZ ESCODA, E.; GREGORI COLOMÉ, J. \& MUÑOZ PÉREZ, A. - Psoas abscess in patients infected with the human immunodeficiency virus. Europ. J. clin. microbiol. infect. Dis., 23: 661$663,2004$.

9. PINTADO, V.; GOMEZ-MAMPASO, E.; COBO, J. et al. - Nocardial infection in patients infected with the human immunodeficiency virus. Clin. Microbiol. Infect., 9: 716$720,2003$.

10. UTTAMCHANDANI, R.B.; DAIKOS, G.L.; REYES, R.R. et al. - Nocardiosis in 30 patients with advanced human immunodeficiency virus infection: clinical features and outcome. Clin. infect. Dis., 18: 348-353, 1994.

Received: 24 July 2007

Accepted: 5 November 2007 